\title{
Karantene - om mer enn sykdom
}

\author{
Ordet karantene var opprinnelig et medisinsk ord som innebar isolering av smittebærere. \\ Nå brukes ordet oftest om helt andre typer utestengning.
}

Hvis man slår opp i en moderne ordbok på karantene, får man vite at ordet har to betydninger. Den ene er «midlertidig isolering av (mulige) smittebærere», den andre «midlertidig utestengning fra idrettskonkurranser» (1). Stadig oftere brukes imidlertid karantene også om mennesker som utestenges $i$ andre sammenhenger, enten det er etter økonomiske forhold (konkurskarantene) eller politikere som går fra politikk til andre bransjer. En av de mest omtalte av disse overgangene var da helseminister Bjarne Håkon Hanssen like etter valget i 2009 hoppet av politikken for å starte kommunikasjonsbyrået First House (2).

\section{Karantene eller ventetid?}

De siste årene har denne type overganger vært mye omtalt, og nylig ble ventetid og saksforbud for toppbyråkrater og politikere som går over til andre jobber utredet (3). Da utvalgslederen Inge Lorange Backer la frem rapporten, sa han at de hadde forsøkt å unngå ordet karantene, fordi ordet «kan gi noen assosiasjoner til sykdom» (2). Jeg rynket pannen. Karantene brukes i dag bare sjelden i medisinsk sammenheng, så hva er problemet?

I rapporten bruker utvalget noe plass på terminologien: «Betegnelsen karantene kan formidle at perioden skal bety en «renselse» og markere en tidsmessig avstand mellom to forskjellige roller. Den er likevel ikke helt treffende, fordi den kan gi inntrykk av at politikeren isoleres og er avskåret fra generelt å engasjere seg og ta ny stilling. Utvalget foreslår derfor å bruke et annet uttrykk, for eksempel 'ventetid'.» (3).

Dette er etter mitt skjønn søkt. I språket er det ofte slik at ordene består, men deres innhold forskyves i takt med utviklingen (4).

Skal man bruke Backers argumentasjon, bør man vel unngå «ventetid» også, fordi det kan gi noen assosiasjoner til adventstiden.

\section{0 dager}

De eldste karanteneforanstaltninger man kjenner, skriver seg fra tiden etter svartedauden på slutten av 1300-tallet (5). Selv om det alltid har vært uenighet om nytten av karantene og om dens varighet (5), forble likevel karantene i mer enn 500 år et viktig smitteverntiltak i Europa (6). I smittevernloven finnes fremdeles regler for karantene, men alt for 15 år siden konklu- derte Aavitsland med at «ny kunnskap om smittemåter gjør at karantene ofte fremstår som irrelevant» (6).

Ordet karantene kommer fra det italienske quarantina (7). Vi gjenfinner det i mange europeiske språk: karantän (svensk), karantæne (dansk), quarantine (engelsk), quarantaine (fransk), Quarantäne (tysk), cuarentena (spansk) osv. På italiensk betyr quaranta tallet 40, og avsperringen i de første bestemmelsene varte i 40 dager (5). Men hvor kom de 40 dagene fra? Ingen vet sikkert. Enkelte mener at man kjente til at inkubasjonsperioden for de fleste smittsomme sykdommer ville falle innenfor en 40-dagersperiode (8), men om grensen var tilfeldig eller empirisk fundert, vet man ikke (9). Bakgrunnen var nok sannsynligvis like mye religiøs som medisinsk (10). Pussig nok ser det ut til at karantenen opprinnelig varte i 30 dager, på italiensk trentina (11).

Tallet 40 har hatt en spesiell plass i religion, tradisjon og kultur (12). Moses var 40 år i ørkenen, fasten kunne vare i 40 dager og Ali Baba hadde med seg 40 røvere. 40 var også en av de kritiske dagene i de hippokratiske skriftene (13), i barselomsorgen i en rekke kulturer (14) osv. Antakelig var det slik at man brukte en allerede eksisterende knagg å henge karantenen på da innsikt og behov i epidemibekjempelsen meldte seg (Torvid Kiserud, personlig meddelelse).

\section{Avslutning}

Noen av de første tiltakene det offentlige helsevesenet i Norge innførte, var karantene- og isolasjonsbestemmelser som vern mot pest. Nå brukes ordet langt oftere $i$ andre sammenhenger. Det er ingen grunn til at det ikke også kan brukes når politikere går over i andre jobber.

\section{Erlend Hem}

erlend.hem@medisin.uio.no

Erlend Hem (f. 1970) er dr.med. og assisterende sjefredaktør i Tidsskriftet.

\section{Litteratur}

1. Karantene. I: Bokmålsordboka og Nynorskordboka. www.nob-ordbok.uio.no/perl/ordbok.cgi? OPP=karantene\&ordbok=begge (1.8.2013).

2. Alstadheim K. Bjarneoppdragelse. Dagens Næringsliv 28.6.2012: 2. www.dn.no/forsiden/ kommentarer/article2425224.ece (1.8.2013).

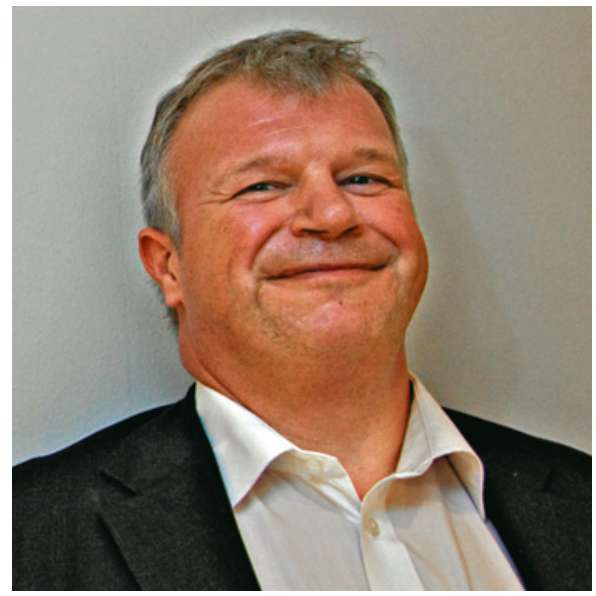

Bjarne Håkon Hanssen trakk seg fra politikken i 2009. Han fikk seks måneders karantene pluss seks måneders saksforbud (2). Foto Dag W. Grundseth, Scanpix

3. Karantene (ventetid). Kap. 7.3.3.2. I: Norges offentlige utredninger. Ventetid - et spørsmål om tillit. NOU 2012: 12. www.regjeringen.no/nb/dep/fad/ dok/nouer/2012/nou-2012-12/9/3/3.html?id= 687000 (1.8.2013).

4. Vinje F-E. Professor emerita. Finn-Erik Vinjes blogg 27.6. 2013. www.finnerikvinje.no/ $\mathrm{blog} / ? \mathrm{p}=18479$ (1.8.2013).

5. G.N. [G. Norrie]. Karantæne. I: Blangstrup C, red. Salmonsens konversationsleksikon. 2. utg. Bd. 13 : Jernbaneret-Kirkeskat. København: J. H. Schultz, 1922: 557. http://runeberg.org/salmonsen/ 2/13/0571.html (1.8.2013).

6. Aavitsland P. En plass for karantene? Tidsskr Nor Lægeforen 1998; 118: 3582. http://tidsskriftet.no/ legacy/199823/leder2.html (1.8.2013).

7. quarantine. I: Oxford English Dictionary. 3. utg. 2007. www.oed.com/view/Entry/155959 (1.8.2013).

8. Haubrich WS. Medical meanings: a glossary of word origins. 2. utg. Philadelphia, PA: American College of Physicians, 2003: 199.

9. Porta M. red. A dictionary of epidemiology. 5. utg. Oxford: Oxford University Press, 2008: 202-3.

10. Rosbach JH. Etymologi for alle. 3. utg. Oslo: Pax, 2009: 121

11. Fortuine R. The words of medicine: sources, meanings, and delights. Springfield, IL: Charles C Thomas, 2001: 227

12. Kiserud T. Hvor lenge varer et svangerskap? Tidsskr Nor Legeforen 2012: 132: 8-9.

13. Skinner HA. The origin of medical terms. 2. utg. New York, NY: Hafner Publishing Company, 1970: 346 .

14. Eberhard-Gran M, Nordhagen R, Heiberg E et al. Barselomsorg i et tverrkulturelt og historisk perspektiv. Tidsskr Nor Lægeforen 2003; 123: 3553-6.

Mottatt 4.8.2013 og godkjent 6.8.2013. Medisinsk redaktør Marit Fjellhaug Nylund. 